\title{
Engaged Couples' Views of About Marriage and Educational Needs Regarding Reproductive and Sexual Health in Turkey
}

\author{
Ebru Inan Kirmizigul ${ }^{1}$ and Gul Pinar ${ }^{2 *}$ \\ ${ }^{1}$ Zekai Tahir Burak Women's Health Training and Research Hospital, Turkey \\ ${ }^{2}$ Department of Nursing, Ylldirım Beyazıt University Faculty of Health Sciences, Turkey
}

Submission: October 02, 2020; Published: October 19, 2020

*Corresponding author: Gul Pinar, Department of Nursing, Ylldırım Beyazıt University Faculty of Health Sciences, Turkey

\begin{abstract}
Abstarct
In Turkey, there is little information about couples' reproductive and sexual health (RSH) educational needs. This study was conducted to determine engaged couples' views of about marriage and RSH educational needs in Turkey in 2015. In a descriptive and cross-sectional study, 514 engaged couples participating in the study were selected by randomly. A questionnaire form was developed by researcher to describe couples' view of about marriage and the need for RSH education. Mann-Whitney U test, Kruskall-Wallis test, Correlation analysis and Ki-square tests was used in data evaluation. Average marriage age of the newly-weds was $27.1 \pm 3.6$ (min:18, max:35) for women, and 29.1 \pm 3.2 (min:20, max:36) for men in the research. Average reproduction health-sexual health scores of the individuals who participated in the research were $44.6 \pm 20.7$ (min:0, max:100). Most of couples mentioned high need for SRH education, particularly in topics related to parenthood and sexuality. As the age group, educational level, employment rate and income level of the participants increased, their reproduction health knowledge scores increased. RSH knowledge score average of the individuals, who did not receive pre-marriage counseling service, who have broken family, who married with arranged marriage and married with relatives, was lower $(\mathrm{p}<0.05)$. It was revealed as a result of the research that the individuals who apply to get married had information necessity about RSH. The results suggest a need for developing comprehensive premarital education for couples.
\end{abstract}

Keywords: Marriage; Pre-marriage counseling; Sexual health; Reproduction health

\section{Introduction}

Marriage potentially brings radical change to couples' life such as sexually, biologically, socially, economically, and emotionally [1-5]. Reproductive and sexual health (RSH) is vital to couples in order to ensure healthy marriage [6]. World Health Organization (WHO) recognized this acute needs on RSH. WHO's first project, which called for promoting marital life and health outcomes such as preventing sexual violence, abuse, unintended pregnancies, adolescent married, sexually transmitted infections (STIs), relationship skills, gender norms, marital satisfaction, communication, conflict resolution, decision making, family budget preparation, expectations from marriage, believes and values particularly in the southern region of the country. In close collaboration with other countries, the WHO established a peer education network to disseminate marriage relationship and RHS information to married couples; supported local health facilities to provide youth-friendly services; and enhanced positive changes in couples' lives and their family.

This approach is recommended for expansion in diverse areas of Turkey. On average, marriages in the last decades, leading to more than one-third of couples in Turkey being remarried. According to the National Center for Health Statistics, the total number of marriages decreased while divorce cases increased in Turkey in 2015 (Ministry of Family and Social Policies, 2011). Despite the acute needs for premarital RSH information for engaged couples, few couples exposure to this information. A research has revealed that married women have more limited support systems and social networks due to extreme cultural and social pressure [7]. Finally, Turkey has a large population of married and engaged with unmet needs for RHS information and services. Morover, SRH educational needs are often concealed in health policy in Turkey [8-11]. The 
goal of the study was to describe engaged couples' views of about marriage and needs of RSH education in Turkey.

\section{Materials and Methods}

\section{Sample and Setting}

This descriptive and cross-sectional study was conducted between June 152014 and September 252014 in Turkey. The population was composed of the women who applied to Cankaya Municipality Department of Marriage within last a year $(\mathrm{N}=6573)$. In order to calculate the sample size, simple random sampling method was used. On this basis, 257 couples (514 individuals) were required. The sample was completed with $95 \%$ confidence. Eligibility criteria for patients were:

a) 18 years or older,

b) can read and write in Turkish,

c) agree to participate in the research.

\section{Instruments}

The Questionnaire Form was developed by the researchers and contained questions directed at determining the couple's socio-demographic characteristics and the needs for SRH education. This form consisted of three sections. 1) there were questions (9 items) about socio-demographic characteristics of the individuals. 2) there were questions (19 items) to determine the opinions of the individuals about marriage. 3) there were questions (19 items) measuring the knowledge levels of the individuals about RSH, family planning and sexually transmitted STIs. Internal consistency reliability is high (alpha $=0.81$ ). The face to face interviews were approximately $20-30 \mathrm{~min}$ each. Internal consistency reliability is high ( $\mathrm{alph}=0.86$ ). The form was easy to apply and was easily understood by the couples, and no problems were encountered during its application. The 20 students were not included in the final sample.

\section{Data Analysis}

The data collected in the study were analyzed by SPSS 20 package program). In statistical analysis number, percentage, mean and standard deviation were used. Mann-Whitney $U$ test was used in the comparisons with two groups as a result of the normality tests of the data, and Kruskall-Wallis test was used in the comparison of 3 and above groups. Correlation analysis or Kisquare tests were used in the relationships between the variables according to the data measurement level. The significance level was $\mathrm{p}<0.05$.

\section{Ethical Considerations}

This study was approved by Dıșkapı Yıldırım Beyazıt Training and Research Hospital, Ethics Committee. In addition during the data collection phase each couples were was informed by a written document that participation in the study was voluntary and their privacy would be strictly protected.

\section{Result}

When the descriptive findings of the participants were analyzed it was determined that the mean age of women was 27.1 \pm 3.6 (min:18, max:35), and the mean age of the men was $29.1 \pm 3.2$ (min:21, max:36). The educational level of $77.2 \%$ of the couples was university graduate, $90.3 \%$ worked at job, $94 \%$ had health insurance, and $84.8 \%$ lived in a nuclear family. When the characteristics of the individuals about marriage were concerned; it was found that the couples who are getting ready for marriage decided to get married after $45.7 \pm 41.6$ (min:12, max: 360 ) months in average following their marriage decision, and $92.4 \%$ married for love, and $6.2 \%$ married with arranged marriage. $96.3 \%$ of the individuals indicated that there was no kinship with their spouses, and $93.4 \%$ received their family's approval after they made a decision on spouse selection.

When the couples who participated in the study were asked to describe marriage, $83.1 \%$ stated that it was "sharing life", $61.7 \%$ "happiness", 44.7\% "taking responsibility", 39.3\% "orderly life", $25.3 \%$ "continuation of lineage", and $14 \%$ said "fulfilling sexual necessities". It was observed that the individuals who participated in the research had expectations mostly from their spouses to have "responsibility sense" (74.3\%), "to be loyal" (73.3\%) and to be "good natured" (72.4\%). 49.8\% of the individuals who participated in the research stated that they would investigate the families of their spouses, $82.9 \%$ said the authority in marriage must be equal in both men and women, $81.7 \%$ approved divorce and divorces occurred in the first five years of marriage, and $61.7 \%$ stated that they would like to have two-three children after marriage. $84.4 \%$ of the individuals expressed that they can talk about sexual issues comfortably with the person they want to get married. $41.6 \%$ of the individuals who applied to get married did not have any anxiety about marriage life; and the individuals who had anxiety stated that they had anxiety about "limitation of their freedom" (18.5\%), "experiencing economic problems" (17.9\%), "not having any children" (16.1\%), and "they will be unhappy with their spouse" (15.6\%). Only $15 \%$ of the individuals who applied for marriage had health screening. $80.4 \%$ of these were for thalassemia, $51.6 \%$ for blood group/Rh determination, $47.3 \%$ for Hepatitis B and C, and 38.3\% for HIV/AIDS.

$70.4 \%$ of the couples indicated that they had counseling before marriage. The issues they received counseling for were preparation for marriage (44.6\%), children raising-parenthood (33.5\%), communication skills (33.1\%), and sexual life (33.1\%). When the resources they used for information were examined, it was determined that $47.9 \%$ of these were "friends", $44 \%$ were "parents", 42.8\% were "married couples", and 9.7\% were "health personnel". However, majority of the couples indicated that they needed more information in the context of counseling before marriage. Information requirements were in turn; learning how to be competent parents $(23.5 \%)$, RSH $(22.8 \%)$, marriage roles (21.6\%), preventing divorce (19.5\%), family planning (18.7\%), marriage preparation (18.3\%), management of family economy 
(12.3\%), and genetically transmitted diseases (10.3\%). $68.5 \%$ of the couples in the research scope indicated that they had adequate knowledge about RSH $(71.2 \%$ about pregnancy, $75.9 \%$ about family planning, and $73.7 \%$ about STI-AIDS).

Total knowledge score average of the couples about RSH was found as $44.6 \pm 20.7$ (min:0, max:100) in Table 1. Seventy-eight of the couples answered right to the question "what is the most appropriate age interval for a healthy pregnancy", $75.1 \% 6$ to the question "when the pregnancy follow up should be started", $64.6 \%$ to the question "which one is the method for protection from pregnancy", $71.6 \%$ to the question "which one is the method to be used after unprotected sexual relationship", and $54.1 \%$ to the question "which one of these is not one of the STI symptoms". It is shown in Table 2 that as the age, income and educational levels of the couples increased, their RSH knowledge scores increased considerably. RSH knowledge score average of the couples who did not work at a job and had broken family was lower $(\mathrm{p}<0.05)$.

Table 1: The distribution of the answers of the couples to the questions on RSH.

\begin{tabular}{|c|c|c|c|c|}
\hline \multirow{2}{*}{ RSH Information Score (Ave. 44.6 \pm 20.7, Min:0, Max:100) } & \multicolumn{2}{|c|}{ Right } & \multicolumn{2}{|c|}{ Wrong } \\
\hline & $\mathbf{n}$ & $\%$ & $\mathbf{n}$ & $\%$ \\
\hline Inter-pregnancy interval & 401 & 78 & 113 & 22 \\
\hline Ovulation cycle & 265 & 51.6 & 249 & 48.4 \\
\hline Pregnancy follow up & 386 & 75.1 & 128 & 24.9 \\
\hline Oral contraceptives & 241 & 46.9 & 273 & 53.1 \\
\hline Condom & 332 & 64.6 & 182 & 35.4 \\
\hline Intrauterine device & 159 & 30.9 & 355 & 69.1 \\
\hline Implant & 24 & 4.7 & 490 & 95.3 \\
\hline Injections & 52 & 10.1 & 462 & 89.9 \\
\hline Tupligation & 105 & 20.4 & 409 & 79.6 \\
\hline Vasectomy & 86 & 16.7 & 428 & 83.3 \\
\hline Emergency contraception & 368 & 71.6 & 146 & 28.4 \\
\hline Using condom correctly & 267 & 51.9 & 247 & 48.1 \\
\hline STIs can be prevented through vaccination & 162 & 31.5 & 352 & 68.5 \\
\hline STI symptoms & 278 & 54.1 & 236 & 45.9 \\
\hline Gonorrhea's definitive diagnosis & 102 & 19.8 & 412 & 80.2 \\
\hline HIV/AIDS transmission ways & 221 & 43 & 293 & 57 \\
\hline AIDS prevention ways & 264 & 51.4 & 250 & 48.6 \\
\hline
\end{tabular}

Table 2: The distribution of RSH knowledge scores of the couples according to socio-demographic characteristics.

\begin{tabular}{|c|c|c|c|c|c|c|c|c|}
\hline \multirow{2}{*}{$\begin{array}{l}\text { Socio-Demographic Character- } \\
\text { istics }\end{array}$} & \multicolumn{6}{|c|}{ RSH Knowledge Score } & \multicolumn{2}{|c|}{ Analysis } \\
\hline & $\mathbf{N}$ & $\overline{\mathbf{x}}$ & Min & Max & SS & Row Ave. & & \\
\hline \multicolumn{9}{|l|}{ Gender } \\
\hline Female & 257 & 46.2 & 0 & 100 & 20.7 & 266.6 & \multicolumn{2}{|c|}{$\mathrm{z}=-1.3^{* *}$} \\
\hline Male & 257 & 43.1 & 0 & 90.5 & 20.6 & 248.4 & \multicolumn{2}{|c|}{$\mathrm{p}=0.162$} \\
\hline \multicolumn{9}{|l|}{ Educational status } \\
\hline Elementary school & 17 & 25.5 & 0 & 47.6 & 13.4 & 112.9 & & Paired comparison \\
\hline High school & 100 & 32 & 0 & 71.4 & 18.1 & 164.3 & $\begin{array}{c}\mathbf{x}^{2} \\
=71.7^{*}\end{array}$ & $3-1$ \\
\hline University and above & 397 & 48.6 & 0 & 100 & 19.8 & 287.2 & $\mathrm{p}=0.0001$ & $3-2$ \\
\hline \multicolumn{9}{|l|}{ Employment status } \\
\hline Yes & 464 & 45.4 & 0 & 100 & 20.8 & 263.3 & \multicolumn{2}{|c|}{$\mathrm{z}=-2.7^{* *}$} \\
\hline No & 50 & 37.2 & 0 & 71.4 & 18.3 & 203.3 & \multicolumn{2}{|c|}{$\mathrm{p}=0.006$} \\
\hline
\end{tabular}




\section{Journal of Gynecology and Women's Health}

\begin{tabular}{|c|c|c|c|c|c|c|c|c|}
\hline Income level & & & & & & & & Paired comparison \\
\hline Income is less than expenditure & 84 & 37.2 & 0 & 81 & 18.9 & 202.7 & & $1-2$ \\
\hline Income is equal to expenditure & 275 & 44.3 & 0 & 100 & 21.2 & 253.4 & $\begin{array}{c}\mathbf{x}^{2} \\
=21.4^{*}\end{array}$ & $1-3$ \\
\hline Income is more than expenditure & 155 & 49.3 & 0 & 90.5 & 19.4 & 294.5 & $\mathrm{p}=0.0001$ & $2-3$ \\
\hline \multicolumn{9}{|l|}{ Family type } \\
\hline Nuclear family & 436 & 46.4 & 0 & 100 & 20.1 & 269.1 & & Paired comparison \\
\hline Broken family & 61 & 31.1 & 0 & 66.7 & 19.5 & 164.8 & $\begin{array}{c}\mathbf{x}^{2} \\
=27.5^{*}\end{array}$ & $2-1$ \\
\hline Large family & 17 & 47.9 & 9.5 & 71.4 & 21.7 & 291.9 & $\mathrm{p}=0.0001$ & $2-3$ \\
\hline
\end{tabular}

**Mann Whitney U Test was used $(p<0.05)$.

When the distribution of RSH knowledge scores of the individuals who participated in the research according to their characteristics regarding marriage was examined, RSH knowledge scores of the ones who were married to relatives and with arranged marriage were significantly low $(\mathrm{p}<0.05)$. RSH knowledge of the couples who received counseling before about the marriage life was higher than that of the couples who did not receive it $(\mathrm{p}<0.05)$ (Table 3).

Table 3: The distribution of RSH knowledge scores based on characteristics of marriage.

\begin{tabular}{|c|c|c|c|c|c|c|c|c|}
\hline \multirow{2}{*}{ Premarital Counseling } & \multicolumn{6}{|c|}{ RSH knowledge score } & \multirow{2}{*}{\multicolumn{2}{|c|}{ Analysis }} \\
\hline & $\mathbf{n}$ & $\overline{\mathbf{x}}$ & Min & Max & SS & Row ave. & & \\
\hline Yes & 362 & 46.4 & 0 & 100 & 20.4 & 268.6 & \multicolumn{2}{|c|}{$\mathrm{z}=-2.6^{*}$} \\
\hline No & 152 & 40.5 & 0 & 90.5 & 20.9 & 231 & \multicolumn{2}{|c|}{$\mathrm{p}=0.009$} \\
\hline \multicolumn{9}{|l|}{ Kinship with the spouse } \\
\hline Yes & 19 & 33.8 & 0 & 66.7 & 19 & 180.3 & \multicolumn{2}{|c|}{$\mathrm{z}=-2.3^{*}$} \\
\hline No & 495 & 45.1 & 0 & 100 & 20.7 & 260.5 & \multicolumn{2}{|c|}{$\mathrm{p}=0.021$} \\
\hline \multicolumn{9}{|l|}{ Marriage decision way } \\
\hline Arranged marriage & 32 & 27.8 & 0 & 71.4 & 19.2 & 141.7 & $\begin{array}{c}\mathbf{x}^{2} \\
=21.9^{* *}\end{array}$ & Paired comparison \\
\hline Marriage for love & 475 & 45.9 & 0 & 100 & 20.3 & 266 & $\mathrm{p}=0.0001$ & 1-Feb \\
\hline $\begin{array}{l}\text { Other (by running away and } \\
\text { in virtual platform) }\end{array}$ & 7 & 37.4 & 9.5 & 66.7 & 21.2 & 207.9 & & 3-Feb \\
\hline
\end{tabular}

**Kruskall Wallis Test was used $(p<0.05)$.

\section{Discussion}

Family is the core of the society. However, becoming a couple is one of the most complex experiences [12-14]. Family factor in Turkey is very influential particularly during the process of marriage. In the recent years, even if the rate of marriage where spouses are chosen on free will increases, couples still prefer to get the consent of their families [15]. In the study (2011), the most of decisions for marriage (82.9\%) are made on the will of the couple and through the consent of their families. The rate for those getting married unwillingly on the request of their families is $9.4 \%$. Furthermore, the leading characteristic which women seek in the potential spouse is "having a job" with the rate of $90.9 \%$, "being beautiful" $54.4 \%$, and "being handsome" 48.5
\% (Ministry of Family and Social Policies, 2011). According to the 2011 survey, for men, the most important characteristics of women to be married are "being in love" (90.1\%), "having similar family structures" (80.8\%), "getting married for the first time" (85.8\%), "being beautiful" (59\%), "having a job" (35.9\%). For women, the most important characteristics of men to be married is "having a job" (95\%), "being in love" (90.4\%), "having similar family structures" (87\%), "getting married for the first time" (79.4 $\%)$, "having more income" (56.7 \%), "being handsome" (43.7 \%), "being more educated" (43.3\%) [16]. In the study, the most of couples wanted their spouse to give them happiness, to be honest and respectful, and a person with whom they could talk like a friend and who love and understand them [17]. Our study showed 
that the individuals who are about to get married perceived marriage as life "sharing" (83.1\%), and had expectations that their spouse had "responsibility" (74.3\%), was "loyal" (73.3\%) and "good natured (72.4\%). Based on the findings of our study and other studies, physical appearance, economical and social characteristics which are realized before marriage may play a role in continuation of marriage.

Premarital consultancy during your engagement can decrease the chances of divorce $[18,19]$. It was emphasized that couples who receive marriage counseling display more efficient and positive behavior in social life, and there is less domestic violence and marriage disagreement $[20,11]$. Although there is marriagepreparation courses for couples who plan to get married offered by the Ministry of Family and Social Policies in Turkey during the recent years, they are not widespread. Routine marriage counseling services are offered to university students in developed countries, in Turkey, premarital consultancy at an early stage for the young is not encountered [21]. An important element of premarital education is RSH for healthier society. In our study, 30\% of the couples who were about to get married did not receive any counseling about marriage preparation. A group who indicated that they received marriage counseling stated that they received information about marriage preparation (44.6\%), transmission to parenthood (33.5\%), and communication techniques (33.1\%), however, they needed more information on these issues. Furthermore, information sources of the couples about marriage were frequently friends, parents and married couples, in contrast information receiving rate from health personnel was found to be quite low $(9.7 \%)$. In different studies, the majority of men received their information from less knowledgeable people such as their friends an media while in the minority of couples had obtained information about RSH via healthcare providers [2,5,15,19,2226]. In the study of Moddi et al performed on couples who apply to marriage preparation classes, it was found that $29.6 \%$ of individuals did not receive any counseling before marriage [5]. Our study results are similar to other studies. According to these results, it can be stated that peer group effect continues on young individuals who step into marriage without preparation and they remain as a great risk group in society. Inadequate level of premarital consultancy for couples may lead to negative health effect on families and in addition can lead to social problems since they will bring extra financial load.

The rate of kin marriage throughout Turkey in 2006 is $21.7 \%$, while this rate increases to $40.4 \%$ in the rural areas, especially in the Southeastern Anatolia Region. As the education level and economic income level decrease, the rate of meeting the first spouse inside the family and kin circles increase [16]. In our study, the rate of kin marriage is $3.7 \%$. Kin marriage is important in terms of preventability of genetic diseases that should be explained to the couples during premarital education. Both the woman and man to get married should not possess a mental development problem, acute syphilis, leprosy, tuberculosis, gonorrhea, AIDS, hepatitis B and C illnesses and genetically transmitted illnesses [27]. However, in our study, $15 \%$ of the couples stated that they received a health report. In fact, one out of five marriages in Turkey is relative marriage $(21.7 \%)$. Relative marriages occur among the first degree relatives the most and this situation leads to an increase in society in the frequency of autosomal recessive transmitted illnesses (phenylketonuria, cystic fibrosis, sickle cell anemia, thalassemia, and galactosemia). Although beta thalassemia carriage frequency in Turkey is $2.1 \%$, in some regions, this can go up to $10 \%$, and there are approximately $1,300,000$ carriers and 4,000 patients [28]. Since premarital consultancy has a crucial role in the management and prevention of many genetic illnesses, genetic counseling to be given to couples who are in the risk group especially is important.

RSH knowledge levels of the couples in our study were under average (average: 44 points, min:0; max:100), however, knowledge score of the group who received marriage counseling was higher. It was determined that the individuals were in search of information prior to marriage on RSH, pregnancy prevention methods and STI, however, they still lacked information since their information sources were not reliable [5,12,19, 29-33]. These results are similar to our research findings. Sexuality in Turkey, where the marriage institution is widespread, is seen as one of the social prohibitions regarded as a shame and tabu and the social gender inequality affects women the most [28]. Based on all of these results, since the couples share little in sexuality issue, it can seem to be among the issues needed less. It is thought that quite low rates of application to the limited number of premarital consultancy units in Turkey especially on RSH issues are effective on this result.

When the relationship between the RSH knowledge scores of the individuals and socio-demographic characteristics was examined in our research; it was observed that as the educational level and marriage age of the couples increased, their knowledge scores increased. It is observed in two studies conducted on couples who applied for marriage, educated and advanced age group had more information about RSH and they had less risky sexual behavior tendency $[19,13,26]$. The results of our study are similar to these researches. As the age and educational level of the individuals increases, they had less problem to reach the needed information and their awareness increased.

In our research, RSH knowledge scores of the individuals who worked in a job bringing income were higher. Other studies found that employment status of men and women affected positively their awareness state about pregnancy protection methods [4,34]. Our research findings are similar to the study results. It is thought that individuals who work and have social security receive expert support more easily and therefore this affects their competency and applications in terms of marriage preparation.

RSH knowledge score in our research showed significant difference according to family type, and the knowledge scores 
of the individuals who have broken family were lower. When the literature was searched, it was indicated that children from divorced families and children who separated from their families and lived in dormitories increased tendency to show risky health behavior $[35,22,13]$. Our research findings are similar to the study results. Since the first information about RSH is learned within family, the individuals may face obstacles in reaching this information when the parents are missing.

It was observed in our research that total knowledge scores of the couples who married for love were higher. In other researches conducted on couples who are getting ready for marriage, score averages of the believes regarding sexuality of couples who met and agreed to marry were found to be higher than those of the couples who married with arranged marriage [19,22,29,36]. In another study, knowledge level (98\%) about family planning method of women who met and got engaged was higher than women who got engaged as arranged (85.2\%) [37]. Our research finding is similar to the study results. It is thought that in couples who married with arranged marriage, family elders affect methoduse by individuals and can play an effective role in many decisions reached about health and may inform them wrongly also [38-45].

\section{Conclusion and Suggestions}

It was observed as a result of the research that the couples approached marriage with hope and at the same time they had some expectations and counseling requirements. Moreover, it was determined in the study that as the number of the couples who received premarital counseling increased, their RSH knowledge scores increased as well. Based on the findings, couples felt the need for RSH education in various areas, and these needs were influenced by social and demographic factors. Therefore, premarital consultancy program could be established in more detail by using multi-disciplinary standard forms or in depth interview forms to measure their attitude about marriage in the department of marriage and family centers by collaborating with municipalities. Also, epidemiological research is deemed necessary to be able to identify stability of marriage.

\section{Limitation}

This research was one of few couples on RSH educational needs in Turkey. However, we cannot generalize the views and knowledge of couples in this study to all Turkish couples.

\section{Acknowledgement}

We would like to express our deepest gratitude to all participants who helped us conduct this study.

\section{References}

1. Gürsoy E, Gençalp NS (2011) Importance of sexual health education. Family and Society Education Culture and Research Journal 6(23): 2936.
2. Char A, Saavala M, Kulmala (2011) Assessing young unmarried men's acsess to reproductive health information and services in rural India. BMC Public Health 11: 476.

3. Wong LP (2012) Qualitative inquiry into premarital sexual behaviours and contraceptive use among multiethnic young women: implications for education and future research. Plos One 7(12): e51745.

4. Ghodsi Z, Hojjatoleslami S (2012) A survey on use of methods and knowledge about contraceptive in married women. Procedia-Social and Behavioral Sciences 46: 3031-3035.

5. Moodi M, Miri MR, Sharifirad R (2013) The effect of instruction on knowledge and attitude of couples attending pre-marriage counseling classes. J Educ Health Promot 2: 52.

6. Keshavarz A, Amrgha AH, Melatkhah N (2013) Effectiveness of marriage education before marriage change irrational beliefs girls. Procedia Social and Behavioral Sciences 84: 520-524.

7. Vural KB, Temel BA (2010) Examination of some factors in the prediction of sexual satisfaction. Journal of Anatolia Nursing and Health Sciences 13(1): 24-34.

8. Bener Ö, Günay G (2013) Attitudes of the young people about marriage and family life. Karabük University Journal of Social Sciences Institute 3(1): 1-16.

9. Kalkan M, Ersanlı E (2008) The effect of the program on development of marriage relationship based on cognitive-behavioral approach. Educational Sciences as Concept and in Application 8(3): 963-986.

10. Yilmaz T, Kalkan M (2010) The effect of the program on development of pre-marriage relationship on the relationship satisfaction of couples. Educational Sciences in Application 10(3): 1893-1920.

11. Yalcın I, Ersever OG (2015) The effect of the relationship development program on the relationship satisfaction levels of university students. Hacettepe University 30(2): 185-201.

12. Pınar G (2008) Perspective of university senior students to marriage. Journal of Family and Society 4(14): 49-60.

13. Wang Y, Yao W, Shang M, Cai Y, Shi R, et al. (2013) Sexual and reproductive health among unmarried rural-urban female migrants in Shanghai China: a comparative analysis. Int J Environ Res Public Health 10(8): 3578-3589.

14. Bilgin V (2000) Knowledge and awareness levels of Turkish society about marriage. Uludağ University 9(9): 565-588.

15. Ekşi B (2005) Thoughts of husband-wife candidates who are at the stage of marriage preparation about marriage and becoming a parent. Family and Society Journal 2(8): 75-84.

16. http://www.tuik.gov.tr/PreHaberBultenleri.do;jsessionid

17. Dennison RP, Koerner SS (2008) A look at hopes and worries about marriage: The view of adolescents following a parental divorce. Journal of Divorce \& Remarriage 48(3/4): 91-107.

18. Pourmarzi D, Rimaz S (2012) Pre-Marrital Reproductive Health Educational Needs of The Youth. Scientific Journal of School of Public Health and Institute of Public Health Research 10(1).

19. Kısa S, Zeyneloğlu S, Yılmaz D, Verim E (2013) Sexual knowledge and believes of couples who are getting ready for marriage. TAF Preventive Medicine Bulletin 12(3): 297-306.

20. Erbek E, Beștepe E, Akar H, Eradamlar N, Alpkan RL, et al. (2005) Marriage harmony. Thinking Man 18(1): 39-47.

21. Avcl HÖ (2014) The issues that are problematic in relationships before marriage of university students and the issues they want to get education. Ege Education Journal 15(1): 279-299. 
22. Yip PSF, Zhang H, Lam T, Lam KF, Lee AM, et al. (2013) Sex knowledge, attitudes and high-risk sexual behaviors among unmarried youth in Hong Kong. BMC Public Health 13: 691.

23. Shiferaw K, Getahun F, Asres G (2014) Assessment of adolescents' communication on sexual and reproductive health matters with parents and associated factors among secondary and preparatory schools students in Debremarkos town, North West Ethiopia. Reprod Health 11(1): 2.

24. Hamamcı Z, Buğa A, Duran Ş (2011) An examination of the knowledge sources of university students about marriage life and their educational needs before marriage. Journal of Family and Society 7(26): 33-50.

25. Siliman B, Schumm WR (2004) Adolescent perceptions of marriage and premarital couples education. Family Relations 53(5): 513-520.

26. Hajizadeh M, Javadnoori M, Javadifar N (2015) Educational needs of adult men regarding sexual and reproductive health in ahvaz, Iran. J Midwifery Reprod Health 3(3): 385-393.

27. Yuksel Ö (2009) Legal Characteristics of Pre-marriage Examinations and Tests. Forensic Sciences Journal 8(4): 37-47.

28. Şimşek H (2011) The effect of social gender inequality on women's reproduction health: Turkey example. Journal of DEÜ Medical School 25(2):119-126.

29. Göz F, Babadağlı B, Altınsoy N, Yıldızoğlu İ (2005) Knowledge and thoughts of young girls in pre-marriage stage about family planning. Journal of Atatürk University 8(3): 47-55.

30. Iliyasu Z, Abubakar IS, Kabir M, Aliyu MH (2006) Knowledge of hiv/ aids and attitude towards voluntary counseling and testing among adults. J Natl Med Assoc 98(12): 1917-1922.

31. Okonofua EF, Coplan P, Collins S, Oronsaye F, Ogunsakin D, et al. (2003) Impact of an intervention to improve treatment-seeking behavior and prevent sexually transmitted diseases among Nigerian youths. Int Infect Dis 7(1): 61-73.

32. Karabulutlu Ö, Kılıç M (2011) Knowledge level determining of university students about sexual health and reproduction. Journal of Anatolia Nursing and Health Sciences 14(2): 39-45.

33. Evcili F, Cesur B, Altun A, Güçtaş Z, Sümer H, et al. (2013) Pre-marriage sexual experience: opinions and attitudes of midwifery department students. Journal of Gümüşhane University Health Sciences 2(4): 486498.
34. Koștu B, Beydağ KD (2009) Genital hygiene behavior of women who applied to the Gynecology polyclinic. Journal of Atatürk University Nursing College 12(1): 66-71.

35. Tang J, Gao X, Yu Y, Ahmed IN, Zhu H, et al. (2011) Sexual knowledge, attitutes and behaviors among unmarried migrant female workers in China: a comparative analysis. BMC Public Health 11: 917.

36. Torun F, Torun SD, Özaydın AN (2011) Rates of belief to sexual myths in men and the factors affecting belief in myths. Thinking Man Journal of Psychiatry and Neurological Sciences 24: 24-31.

37. Apay SE, Pasinlioğlu T (2008) Family planning methods of engaged couples that they think to use after marriage. Journal of Atatürk University Nursing College 11(4): 30-37.

38. Buss DM (2006) Strategies of human mating. Psychological Topics 2: 229-260.

39.h t t p : / / y e n i a i l e t o p l u m.a i l e.gov.t r / $\mathrm{d}$ a t a / 54293 e a 2369 d c 32358 e e 2 b $25 /$ kutuphane_61turkiyedeailedegerleri.pdf.

40. Kılıç D, Kaygusuz C, Bağ B, Tortumluoğlu G (2007) Thoughts of university students on spouse selection and marriage. Health and Society Journal 17(1): 32-42.

41. Stahmann RF (2000) Premarital counseling: a focus for family therapy. Journal of Family Therapy 22(1): 104-116.

42. Stanley SM, Amato PR, Johnson CA, Markman HJ (2006) Premarital education, marital quality, and marital stability: findings from a large, random household survey. J Fam Psychol 20(1): 117-1126.

43. Türkarslan N, Suleymanov A (2010) Opinions and thoughts of university senior students on marriage -Azerbaijan and Turkey comparison. Karadeniz Journal 5: 54-67.

44. World Health Organization (2001) Programming for male involvement in reproductive health report of the meeting of WHO regional. Advisers in Reproductive health. Washington DC, USA, p. 180.

45. Yılmaz A, Tanrıverdi HM, Gücük S, Akan Z (2013) Contraception knowledge levels of couples who applied to Van provincial center for marriage. Dicle Medical Journal 40(3):453-457.

\section{Your next submission with Juniper Publishers will reach you the below assets}

- Quality Editorial service

- Swift Peer Review

- Reprints availability

- E-prints Service

- Manuscript Podcast for convenient understanding

- Global attainment for your research

- Manuscript accessibility in different formats

( Pdf, E-pub, Full Tsext, Audio)

- Unceasing customer service

Track the below URL for one-step submission

https://juniperpublishers.com/online-submission.php 